\title{
The Effect of Global Economic Crisis on Service Delivery in Selected Non-Governmental Organizations in Kenya
}

\author{
Ogutu Christine \\ Veterinaires Sans Frontieres Germany (VSF-G) - Nairobi \\ Department of Finance \\ P.O. Box 25 653-00603, Piedmont Plaza, Ngong Road \\ Nairobi, Kenya \\ Tel: +254-3873662/76, +254-722-387-733Ｅ-mail: tinaogutu@yahoo.com \\ Mang'unyi Eric Ernest (Corresponding author) \\ Department of Research, The Catholic University of Eastern Africa \\ P.O. Box 62157-00200 \\ Nairobi, Kenya \\ Tel: +254-721-973-630Ｅ-mail: mangunyie@gmail.com, mangunyie@yahoo.com
}

$\begin{array}{lr}\text { Received: August 4, } 2011 & \text { Accepted: August 16, } 2011 \quad \text { Published: December 17, } 2011 \\ \text { doi:10.5430/jms.v2n4p101 } & \text { URL: http://dx.doi.org/10.5430/jms.v2n4p101 }\end{array}$

\begin{abstract}
This study explored the effects of global economic crisis on service delivery in selected non-governmental organisations (NGOs) in Kenya. It was of the view of the researchers that NGOs must have experienced the effects that were brought about by the Global Economic Crisis (GEC) and must have had alternative methods that were used effectively. A number of challenges were faced such as reduction in project implementation, operation scale-down, budget reduction, decreased funding, employment freeze and staff turnover. Service delivery on program activities were affected in various ways such as reduction in staff which in turn scaled down on operations. Main management strategy employed was restructuring. The study recommends that NGOs need to focus on diversifying sources of funding. NGOs should find creative and innovative ways of not only surviving such times but also even possibly seizing them as an opportunity and make a significant difference. Raising awareness among stakeholders, developing agreements among management and staff on clear criteria and measures to manage reserves, unrestricted funds and investment decisions can be utilized.
\end{abstract}

Keywords: Global Economic Crisis, Non-Governmental Organisations.

\section{Introduction}

\subsection{Background of the Study}

According to Teka \& Magezi (2008), the financial crisis that alarmingly threatened to collapse the global economy came in three stages. Firstly, the authors note that there was a decline of the stock indices of the world's leading banks and financial institutions in 2007 which was provoked by a transfer of risk capital from developed markets to emerging markets. Secondly, the authors state that in early 2008 the crisis unfolded again which resulted from a continuing fall in world stock markets that spilled over from 2007. This in turn resulted to fallout triggered by the redirection of cash flows from one class of assets to another, particularly to commodities and energy resources (Danylyshyn 2008; Hilsenrath et al, 2008) as cited in (Teka \& Magezi, 2008). The authors further affirm that third wave of the global financial crisis is currently unfolding. This crisis is being defined by a serial bankrupting of the world's leading financial companies though interventions such as government bailouts and the International Monetary Fund (IMF) are being implemented to help ease the situations.

International Monetary Fund confirm that the financial crisis was said to be more global compared to others that have been experienced in the last sixty years. According to the findings of the IMF (2009) report the global financial crisis initially affected the west advanced economies and the low income countries in various ways. The advanced economies 
are said to have been affected first with the banking crisis in both the United States of America and Europe. The emerging markets were characterized with cross border financial linkages through capital flows, stock market investors and the exchange rates while lags were evident in the less developed countries.

As Lustig (2000) notes, financial and economic crises have devastating impacts on a country's ability to develop fully through reducing and eliminating problems such as poverty, illiteracy, diseases and social injustice. He argues that economic crises typically have an asymmetric impact upon poverty, that is, the increase in poverty brought about by a one percent contraction in output is higher than the decrease in poverty brought about by a one percent increase in output. Such crises can have therefore lasting negative impacts upon poverty reduction efforts (Lustig, 2000).

According to Sender and Uexkull (2009) the impact of the global economic crisis on developing countries is varied depending on the degree to which their economies are linked to the global markets. However, they note that this has led to substantial changes within the economy with negative consequences for workers and especially the poor. For instance, they note that there is an ongoing steep decline in real wages caused by food price inflation combined with stagnation in nominal wages. The crisis has also led to a substantial reshuffling of export portfolios (Sender and Uexkull, 2009).

In his discussions on global financial crisis Mwega (2009) noted that the global financial crisis did not spare Kenya and its challenges are felt over. He notes that the banking sector was greatly hit by the crisis. For example, he says that the stock market and the agricultural sector were greatly affected. In addition, he affirms that the direct impact on the NGO sector was through the reduction of donor funding and the reduced income that was coming from the diaspora.

The global financial and economic crisis has affected African countries and people causing severe social and economic upsets. Growth, macroeconomic stability, employment, and sustainable livelihoods are jeopardized as well as economic and social progress achieved during recent years. NGOs have not been left out since they play an important role in any economy. Though studies on global economic and financial crises have been done, however, no study has actually been carried out on its strategic implications on service delivery in the non-governmental organizations sector, hence the basis of this study.

\subsection{Overview of NGO Sector in Kenya}

In Kenya, NGOs have taken a lead role in the development of the country. Various NGOs with both local and international funding have been in the forefront of fighting hunger, disease and poverty. These NGOs operate at various levels right from the grass roots where they work directly with the communities to the international level where they represent the interest of the country. Registered under the Act of Parliament 1990, the National Council of NGOs also called the NGO Council has registered 5500 national Kenyan NGOs and 500 international NGOs (Ngumuta, 2008).

Onyando (1999) affirms that the growth of the NGO sector has been evidently common everywhere in the world. This she says has been attributed to the comparative advantage component which is explained as the ability of the NGOs to deliver emergency relief or development services cost-effectively to those most in need. Non-Governmental Organizations can reach groups that the government and other agencies cannot, and past development strategies have given NGOs the legitimacy to act on behalf of the poor. According to World Bank estimates, NGOs contribute about $\$ 180$ million annually to rural water supply schemes alone. This is three times the volume of loans advanced by the World Bank itself for such schemes.

Recently, the organizations have been faced with challenges ranging from funding; strategy changes hence somehow affected provision of its core activities. All this have been attributed to the global economic crisis. Discussions and interviews with staff at various levels indicated that there is a general feel that the global economic crisis has brought with it various implications to the NGO sector. It is against this background that the researchers sought to carry out an empirical study on strategic implications of the global economic crisis on the service delivery by NGOs.

\subsection{Statement of the Problem}

Since the beginning of the global recession and financial crisis in the US and other European countries, specifically by the end of 2009, the global recession and financial crisis had stretched across the world over. A crisis which emerged in developed countries had already spread to the developing world making an impact more and more in both the developed and developing world. An increasing number of local development organizations (LDOs) found themselves strategically affected by this development and falling resources at a time when many of their citizens faced economic problems due to the recession and nobody was able to forecast what will be the full extent and duration of the crisis.

The global economic crisis created difficulties on both supply and demand sides of NGOs (Ghanim, 2009). The author claims that level of programme activities was reduced and management strategies and policies were changing. For example, reorganization of operations and changes in reporting lines occurred in both international and local NGOs. 
International Labour Organization, ILO (2009) concurs by saying there was a freeze on hiring and some employees were made redundant. ILO further notes that there were reduced operations among many NGOs operating across international borders.

Forecasts of growth in developing countries have been downgraded significantly in recent times and questions linger as to how deep, how long these difficulties will stretch, the actual and possible effects on service delivery by NGOs, the possible policy implications, what effects the economic crises has on the management strategies adopted by NGOs in Kenya and the appropriate strategic responses for NGOs. Preceding researches on the impact of economic crises have focused at the macro national level with little attention devoted to the effects of the global economic crisis on service delivery by local development organizations, such as NGOs. It is with this regard that this study therefore intended to study the effects of the global economic crisis on service delivery in the NGOs sector in Kenya.

\subsection{Research Questions}

a) What is the effect of economic crises (level of funding) on the management strategies (restructuring, policy change in reporting lines and service level agreements) adopted by the NGOs in Kenya?

b) What are the strategic management implications (cuts in funding) of the global economic crisis (level of funding) on service delivery (health, education, employment and skills, household income and savings and investments) among NGOs?

c) What is the effect of the level of funding to service delivery (health, education, employment and skills, household income and savings and investments) in non-governmental organizations

\subsection{Significance of the Study}

This study is of significance to NGOs, policy makers, researchers and to strategic management students. To the NGOs the study provides important information on how to better manage and sustain development during such difficult economic times. It contributes to improving an understanding about coping strategies that can be put into practice in the event of such a crisis.

\subsection{Scope and Delimitation of the Study}

This study was delimited to Nairobi Province, the capital city of Kenya. This is because the highest number of NGOs headquarters are domicile in Nairobi and have their branches across the country which was thought will give a true reflection of the subject under study. The researchers were confined to twenty one (21) NGOs working on different programme areas in the country (see Table1) since it was not possible to collect data from all NGOs operating in Kenya because of the time limit and limited financial resources. In addition, the study focused solely on the strategic implications of the economic crisis on service delivery in the NGOs, in order to understand how the global economic crisis impacted on their delivery of service and the coping strategies the selected organizations employed. It focused on the period the crisis is believed to have been observed that is between years $2007-2009$. The study relied on responses from selected project managers in Nairobi. Project managers were included in the study because they were thought to have the relevant information that was sought since they head and oversee various projects that receive funding from donors.

\subsection{Conceptual Framework}

In order to unearth the strategic implications of the global economic crises on service delivery in the non-governmental sector, the study strives to isolate the key variables underpinning the global economic crises mainly funding levels, the NGOs strategic focus in terms of policy change, reporting lines and service level agreements as the key considerations in the performance of NGOs service delivery as illustrated in Figure 1. From the conceptual framework, it is discernible that there are three variables under study. The economic crises, which is the main independent variable consisting of level of funding while the NGOs managing strategy comprising of changes in policies and reporting lines constitutes the intervening variable. Service delivery measured in terms of rate of increase and/or improvement in health and education standards, employment levels and skills, household income that is how much a household is able to raise in a month, saving and investment is the key dependent variable under study.

The intervening variable is the strategy employed. For example, restructuring meaning reorganizing the operational or other structures of a company for the purpose of making it more efficient or better organized for its present needs. The global economic crisis affects directly the level of funding for NGOs which directly affects services offered. For example, reduction in the funds received will result in reduced number of employees consequently affecting the quality and quantity of services reaching the beneficiary. In addition, new Service Level Agreements (SLAs) are negotiated considering beneficiaries of service and employees. For instance, employees where service contracts are terminated or 
not renewed after expiry while for beneficiaries, quantity of services is reduced or even cut through increasing the turn around time. Reorganization also occur which is in form of changing reporting lines.

\section{Literature Review}

\subsection{Background of the Global Financial and Economic Crisis}

Hanfstaengl (2009) asserts that the financial and economic crisis has reversed recent positive economic trends in both advanced and developing countries in the past two years. The crisis emerged in major developed economies and spilled over into the developing countries and economies in transition through international financial and trade channels (Hanfstaengl, 2009). This deteriorating international economic environment persisted during the first half of 2009, posing tremendous challenges to developing countries in financing development. A majority of developing countries experienced a reversal in the robust growth. There are indications that a significant setback in the progress made for instance, poverty reduction for many developing countries will continue for a while she asserts.

According to the United Nation, UN (2010) output in the world as a whole was estimated to have declined by more than $2 \%$ in 2009. The report further says output per capita fell in 107 of the 160 countries monitored by the UN Secretariat. In addition, the volume of world trade fell by an estimated $12.5 \%$ according to the report. Developing country export prices also fell relative to import prices, similar to the terms of trade of these countries which fell by $6 \%$ on average (IMF, 2009). In many countries real income fell as well remittances dropped significantly and foreign direct investment and other private flows declined. The IMF estimated that there was a net outflow of private financial resources from emerging and developing countries in 2009. However, several developed countries and emerging countries have taken to large scale stimulus plans to help stabilize and prevent the destructive effect of the crisis (IMF, 2009).

\subsection{The Concept of Financial Crisis}

Adamu (2009) states that the term financial crisis is applied broadly to a variety of situations in which some financial institutions or assets suddenly lose a large part of their value. In the 19th and early $20^{\text {th }}$ centuries, many financial crises were associated with banking panics, and many recessions coincided with these panics (Adamu, 2009). Other situations that are often called financial crises include stock market crashes and the bursting of other financial bubbles, currency crises, and sovereign defaults (Kindleberger \& Aliber, 2005, Laeven \& Valencia, 2008).

\subsection{Theories and Models of Financial Crisis}

Different authors attempt to explain economic crisis based on different considerations. This study explains implications of the global economic crises based on Minsky's model. These theories hold the key to unearthing the mysteries of the financial crises as explained in the ensuing paragraphs.

\subsubsection{World Systems Theory}

Martínez-Vela (2001) defines this theory as a social system with boundaries, structures, member groups, legitimate rules and coherence whose life is made up of the conflicting forces which hold it together by tension and tear it apart as each group seeks eternally to remold it to its advantage. It is characterized by organism such that it has a lifespan over which its characteristics change in some respects and remain stable in others. Life within it is largely self-contained, and the dynamics of its development are largely internal (Martínez-Vela, 2001).

\subsubsection{Coordination Games Theory}

Coordination games, a mathematical approach to modeling financial crises emphasizes that there is often positive feedback between market participants' decisions (Krugman, 2008). Positive feedback implies that there may be dramatic changes in asset values in response to small changes in economic fundamentals. There may be an equilibrium, in which market participants invest heavily in asset markets because they expect assets to be valuable, but there may be equilibrium where participants flee asset markets because they expect others to flee too (Krugman, 2008).

\subsubsection{Herding and Learning Models}

A variety of models have been developed in which asset values may spiral excessively up or down as investors learn from each other. In these models, asset purchases by a few agents encourage others to buy too, not because the true value of the asset increases when many buy, but because investors come to believe the true asset value is high when they observe others buying (Cipriani \& Guarino, 2008). In herding model, it is assumed that investors are fully rational, but only have partial information about the economy. In this model, when a few investors buy some type of asset, this reveals that they have some positive information about that asset, which increases the rational incentive of others to buy the asset too. Even though this is a fully rational decision, it may sometimes lead to mistakenly high asset values implying, eventually, a crash since the first investors may, by chance, have been mistaken. 
Cipriani \& Guarino (2008) affirm that in adaptive learning or adaptive expectation model, investors are assumed to be imperfectly rational, basing their reasoning only on recent experience. Hence, if the price of a given asset rises for some period of time, investors may begin to believe that its price always rises, which increases their tendency to buy and thus drives the price up further. Likewise, observing a few price decreases may give rise to a downward price spiral, so in models of this type large fluctuations in asset prices may occur. Agent-based models of financial markets often assume investors act on the basis of adaptive learning or adaptive expectations (Cipriani \& Guarino, 2008).

The study examined Minskey’s model because it indicates the cyclic movements of the economy and its activities hence, optimism is high in the market during the boom phase experienced with a lot of activities and risks being undertaken by players. However, a slow in economy affects the activities thus spending decisions are negatively affected.

\subsubsection{Minsky’s Model}

According to Frenkel and Rapetti (2009), Minsky's model of financial crisis affirms that the crises are always preceded by a period of economic and financial boom. During the booming phase, there are widespread optimistic expectations about the future. Confidence increases and risk perception reduces. In this environment, economic agents take risky positions and the system becomes increasingly fragile. At some point, some event calls agents' attention about the high degree of exposure to risk in the system. A phase of distress begins. The emerging perception of higher risk makes most agents switch their portfolios in favour of safer and liquid assets. The excess demand for liquidity and low-risk assets ends up pricking the bubble, which results in a massive loss of wealth. In this contractive phase, pessimistic expectations are dominant (Frenkel \& Rapetti, 2009).

Negative feedback effects are the rule in the contractive process, just as positive ones prevailed during the booming phase (Adamu, 2009). The deflationary developments in the financial markets turn most agents either liquidity-constrained or bankrupt, affecting in either case their spending decisions negatively. Private consumption falls and investment collapses. What started as a contraction in the financial sector has now spread out to the whole economy. The financial crisis leads to a systemic economic crisis (Frenkel \& Rapetti, 2009). Minsky’s theory theorises that financial fragility is a typical feature of any capitalist economy and financial fragility levels move together with the business cycle (Adamu, 2009).

\subsubsection{Summary of the Theories and Models}

The above theories are some economic theories that explained financial crises and include the world systems theory which explained the dangers and perils, which leading industrial nations are now facing at the end of the long economic cycle, which began after the oil crisis of 1973. Coordination games theory, a mathematical approach to modelling financial crises has emphasized that there is often positive feedback between market participants' decisions (Krugman, 2008). Where positive feedback implies that there may be dramatic changes in asset values in response to small changes in economic fundamentals.

Minsky's theorises that financial fragility is a typical feature of any capitalist economy and financial fragility levels move together with the business cycle. But the Herding and Learning models explain that asset purchases by a few agents encourage others to buy too, not because the true value of the asset increases when many buy, but because investors come to believe the true asset value is high when they observe others buying (Cipriani \& Guarino, 2008).

\subsection{General Effects of the Global Economic Crises on the Socio-Economic Conditions}

This section generally discusses the effects of the global economic crises on social and economic aspects of both the beneficiaries and organizations and how these impacts on the general economy of the country based on unemployment, poverty, hunger, health, and education dimensions.

\subsubsection{Unemployment}

The International Labour Organization, ILO (2009) points out that the global economic slowdown is affecting low-income groups disproportionately. Of the 20 million jobs lost through the crisis, almost 11 million were in medium and low-income countries (ILO, 2009). To the formally unemployed, must be added those taking deep income cuts from working part-time and those who have given up looking for work in the formal sector. ILO forecasts that employment in high growth domestic product per-capita countries may not return to pre-crisis levels before 2013, unless more decisive measures are taken to stimulate job creation.

In emerging and developing countries, high-quality jobs have been lost and affected workers are likely to move into the informal economy. In developing countries, employment levels could start recovering from 2010, but may not reach pre-crisis levels before 2011 (ILO, 2009). Related to unemployment is social unrest specifically in regions that are particularly vulnerable to tensions and political instability where a reported increase in social tensions within communities 
has been reported. Protest activities, including strikes by government employees, labour sit-ins by industrial workers and demonstrations by the general public, have been reported in the past few years throughout the world (ILO, 2009).

\subsubsection{Poverty}

According to the UN (2009) efforts to eradicate poverty was predicted to be hampered by the global economic crisis thus substantially slowing down efforts put in place. The UN says that the hard won ground was being lost and that all estimates point to the fact that progress on the Millennium Development Goals (MDGs) target of reducing by half the proportion of people living on less than one dollar a day was slowed or halted by the global economic crisis. This new reality for many countries might mean failing to achieve their poverty reduction targets. On the same note, according to World Bank data (2009), it was projected that in 2009 about 100 million more people were trapped in extreme poverty, that is living on less than $\$ 1.25$ a day than was anticipated before the onset of the crisis (UN, 2009).

\subsubsection{Hunger}

On a similar note, FAO (2009) says that the cumulative effects of recent global crises have already resulted in a sharp increase in hunger around the world. They acknowledge that, more than one billion people are victims of hunger. For example, in the year 2008, this number increased by 100 million people (FAO, 2009). Lower incomes due to the economic crisis and persistently high food prices have proven to be a devastating combination for the world's most vulnerable populations adds FAO. According to the World Vision International-Kenya vision, which endevours to ensure that every child lives a life in all its fullness and given the general effects of economic crises the organizations mandate is therefore increased to a larger extent but with the limited resources this becomes a challenge.

\subsubsection{Health}

World Bank (2008) confirms that there is negative trend on all dimensions of health. That is, status of health, the utilization of health services and health expenditures. Malnutrition, especially micronutrient deficiencies, could increase as more households are forced to switch to less nutritious foods (World Bank, 2008). They continue to state that, persons who do not consume the right amount of nutrients become more prone to health problems, learn less and suffer from lower productivity. Even a few months of inadequate food and nutrition can condemn a child for life. It is estimated that higher food prices have already increased the number of children suffering permanent cognitive and physical injury due to malnutrition (World Bank, 2008).

Similarly, Hossain (2009) in her study notes that the economic crises have taken a toll on the psychological health of many vulnerable and poor households. Through household surveys and interviews she suggests that depression, drug and alcohol abuse are on the rise. The consumption of strong local brews in several countries is also high. Similarly, many people interviewed reported rises in domestic violence. In several higher-income countries, past crises show a close association between economic hardship and suicide (Hossain, 2009). There is also cut back on health spending where people are reported to be switching from private to public health care services or are avoiding going to the doctor altogether.

\subsubsection{Education}

The global economic crisis is said to have a detrimental impact on education achievements in many countries. Country case studies already indicate negative trends where vulnerable households report difficulties in meeting school costs forcing them to move children to cheaper institutions or to schools that provide food or material support (World Bank, 2009). However, time and time again, parents who were interviewed emphasized that they were trying to keep their children in school, which they saw as a key to a better future. How many of them will succeed is in doubt: there are a growing number of reports of increased absenteeism, school drop-outs and increases in child labour.

\subsection{Effects of the Global Economic Crises on NGOs Management Strategies}

Under this section, the management strategies that NGOs have resorted to due to the global economic crises are discussed. They are strategies that are in place to help the management of organizations survive the tough economic conditions experienced.

\subsubsection{Restructuring}

According to Integrated Regional Information Networks, IRIN, (2008), some of the biggest development and humanitarian NGOs were laying off staff or revising programmes as their income streams flattened because of the global financial crisis. Fundraising experts of three of the world's top NGOs that is Oxfam International, Save the Children UK and World Vision confirm that programme growth will slow as a result of the squeeze. In an interview with Oxfam International director of finance and information systems, IRIN (2008) states that the growth that had been assumed when putting plans together was not materialising, and that the overall picture was essentially flat. For instance, they 
note that Oxfam had envisaged five to six percent growth over years 2009-2010, but has now revised this to zero. Some of the biggest reductions are coming from corporate donors in the financial sector.

According to Tanya Steele, supporter relations and fundraising director for Save the Children in London as quoted by IRIN (2008), the fall-off with corporate started earlier. She further state that the financial services and investment banking sector have been very generous in the past but since the crisis began it will be tough period for NGOs. The expectation from such institutions is that their support will be flat or potentially decline. On the same note, an interview by IRIN with World Vision's director of advocacy and government relations Robert Zachritz notes that growth from corporations would not be as much hence scaling up of programmes will seize. As a result, NGOs such as Save the Children-UK will not be able to make substantial investments in existing or new programmes (IRIN, 2008). For example, Aid groups are cutting back on support rather than programme costs. It is estimated that the cutbacks will be 10 to 15 percent including staff at headquarters and regional centres to create more cost-effective operations. World Vision's director of advocacy and government relations Robert Zachritz as quoted by IRIN (2008) points out that recipients of micro-credit programmes, such as poor farmers who receive loans to buy tools, seeds and fertilisers, could be particularly hard hit. This is because much of this relies on getting loans from banks. He further states that losing this credit is a huge problem for the world's poor, small-scale farmers (IRIN, 2008).

\subsubsection{Hiring Freeze}

Another strategy employed by other NGOs which receive government funding and are also in a less dire situation is putting a freeze on hiring (IRIN, 2008). Contrary to reduced funding, organizations like the International Rescue Committee (IRC), which helps relocate refugees and rebuild lives in the wake of disaster in 42 countries, receives over 75 percent of its funding from European governments, the US government, the UN and the World Bank, its funding has increased since October 2008 (IRIN, 2008). So far, it has not had to cut back programmes or lay off staff, but it has imposed a hiring freeze, only filling critical positions.

\subsubsection{Reduced Operations / Service Delivery}

Non-Governmental Organizations have also resorted to these measures, an example being the Catholic Relief Services (CRS). According to the Executive Vice-President of Charitable Giving Michael Wiest as quoted in an interview by IRIN (2008), CRS already had in place plans to reduce, over a three-year period its operations in East Asia, Eastern Europe and South America in favour of increased growth in Africa, South Asia and the Middle East. Wiest confirms that there is a sharp reduced programming in the three areas. This is to maintain a degree possible in efforts in Africa, Pakistan and Afghanistan. Programmes cut include economic development in agriculture, micro financing and Maternal Child Health $(\mathrm{MCH})$, while the programmes benefitting Africa range from anti-retroviral therapy and other AIDS projects such as care for orphans, agriculture, microfinance and water development (IRIN, 2008).

The study aimed at establishing the direction that has been taken by the non-governmental organizations as a result of the economic crises. This will be in terms of the programme outreach and the extent of the current programmes being undertaken.

\subsection{Impact of the Global Economic Crises}

International Non-Governmental Organisations (INGOs) are beneficiaries of economic prosperity and social responsibility. The current financial crisis and its anticipated effects will create difficulties on both the supply and demand sides for NGOs (Ghanim, 2009). Ghanim states that on the supply side, the pressure on government budgets, that is unavoidable given the rescue and recovery packages may squeeze the appropriations to international development assistance in all its forms. Policy makers and legislators in donor countries may start to further narrow the coverage of their overseas development assistance to the countries that offer the best interface for aid-trade-security. Other difficulties will come from the anticipated reactions by various governments in Africa which will be compelled to find ways to increase revenue, reduce deficit, and to compensate for the restricted access to loans/credits from the international capital markets. In addition, (Ghanim, 2009) affirms that increase in food and fuel prices will aggravate the macroeconomic problems. Hence, many governments in Africa will be forced to restructure their subsidy, address fluctuations in the value of hard currency, increase tax and duties to increase revenue, and may also gravitate to put more restrictive measures to control government expenses on social services at a time when the private sector including foreign investors will also be under serious pressure and, hence, would not be able to move quickly and fill gaps.

On NGOs, the crisis will also create balance sheet challenges which will be under pressure to cover fixed and operating costs at the expense of investment on systems and program quality. (Ghanim, 2009) further notes that on the demand side, International NGOs will face increasing pressure to provide safety nets and social services for poor people, purchase project inputs at higher costs, increase the remuneration for their staff to offset some of the inflationary trends 
in the cost of living, and will face either delays or acute problems securing community and host government contributions to projects. All these may also create contagion effects on local NGOs. International NGOs may also face serious relationship problems with communities and local governments if they see a sharp decline in charitable giving by individual and private donors. A blend of these difficulties combined with strained operating budgets for supervision and control most likely will create environments conducive to fraud and corruption as (Ghanim, 2009) asserts.

\subsection{Implications of Global Financial and Economic Crisis for NGOs}

There is a slowing growth of humanitarian activities, for example, Gross (2008) in Teka and Magezi (2008) say that fundraising experts of the world's top NGOs such as Oxfam Great Britain and Save the Children-UK and World Vision of the USA stated that programme growth slowed as a result of the squeeze. Oxfam's finance and information systems director, John Shaw, stated that the growth that was assumed when putting plans together was not materializing and that the overall picture is essentially flat (IRIN, 2008). Investor Relations Information Network (IRIN, 2008) further notes that this is a very serious reality given the size and capability levels of these big three NGOs. This is because the three NGOs alone make an annual income of US\$ 1.8 billion.

Ho (2008) indicates that another occurrence is virtual setbacks in donor resources. He acknowledges that nearly every organization funding stands at less value today than it did, and some considerably so (Ho, 2008). In addition, he notes that NGOs work will be dramatically reduced hence direct consequence of job losses and the collapse of firms that make up a major pool of contributors towards NGOs activities. For example, in the US, the number of donors already fell by an average of $3.8 \%$ in the first half of 2008 from 2007 he states. He further notes from a survey of 439 of the richest families undertaken in 2007 by the wealth research firm Prince and Associates that $73 \%$ of respondents said they already felt a significant adverse impact from the current economic environment while $51 \%$ said they planned to contribute less in charity.

Job losses, inflation and steep prices are certain to influence against charity work. This is because people first prioritise to meet their own needs and bills and then make charitable gifts to organizations (Ho, 2008). Chossudovsky (2008) in Teka and Magezi (2008) says that private donors will be able to assess their losses most rapidly and cut their commitments almost immediately. According to IRIN (2008), one sure thing these insights reveal is that the global financial crisis is likely to see cuts in official development aid although the extent to which this might happen is unpredictable and there may be drops ranging from just a few percentage points to one-third (IRIN, 2008).

However, Chossudovsky (2008) argues that, in the face of coming funding challenges caused by the crisis, AIDS treatment could enable those organisations whose activities revolve around the HIV and AIDS pandemic to continue. He provides a number of reasons in this regard. One is the mere fact that assistance to HIV and AIDS has significantly increased over the past years. But most recently, more funding is being channelled towards treatment over prevention. From a policy point of view, this is due to the sense of privilege to care being ascribed to seropositive people, especially in the poorer regions of the world (Chossudovsky, 2008). He contends that some experts believe that donors are likely to respond positively to the AIDS case by preserving AIDS treatment while cutting other parts of assistance budget. In addition, he says that those working in the field of HIV and AIDS would be tactful to focus activities on treatment. This would create potential funding avenues. Equally, some experts believe that multilateral assistance, even for HIV and AIDS, might be just as affected. This is because the financial crisis is causing many donor governments to turn inwards to their own ailing economies thus affecting the activities of dependant organizations.

\subsection{Strategies Adopted by NGOs during the Global Economic Crisis}

Non-Governmental Organizations are already devising creative ways of helping themselves to weather the current storm. They are trying to innovate their way out of the financial squeeze. Teka and Magezi (2008) confirm that NGOs are embracing various cost-effectiveness strategies. Given the reality of funding uncertainty, they say that NGOs are either prioritising activities or cutting back some variable costs. For example, Oxfam's response is not to slash programmes but to cutback support in the form of laying-off redundant staff at both headquarters and regional centres, thus cutting 10 to $15 \%$ of variable costs (IRIN 2008). Dan Timms, Oxfam's spokesperson in IRIN notes operations are being streamlined in the UK which includes redundancies and also not filling some vacancies. Ambitious direct marketing and advertising plans are also being affected through cost-cutting measures. For example, comparing the marketing and advertising to the actual programmes in the field, which are thought to have a low priority, Oxfam is going to be reining on spending on those kinds of things the spokesman notes.

In addition, Lurma Rackley, CARE public relations director in Teka and Magezi (2008) state it would be a last resort to reduce their programmes. What we would do, however, is to slow down expansion and possibly reduce the number of staff through hiring freezes or postponing programme expansions. 
Similarly, according to IRIN (2008), Save the Children-UK opts to refrain from expanding their activities as a cost-cutting strategy. Non-Governmental Organizations are urged to develop organisational fundraising teams instead of spending on fundraising consultants as Frank (2008) advises. She further asserts that cost-effectiveness can also be obtained through cost-containment strategies such as frugality. That is, using donor money as if it were one's own as a means to eliminate wasteful spending. This would not only save funding, but also potentially earn more funding as it would be donor-friendly.

Frank (2008) says cultivation of donors is another response which may include investigating the possibilities of recruiting previous donors; getting existing donors, to commit more funds by drawing up a funding proposal designed around an organisation's strengths and achievements rather than its current financial sorrows; or by exploring new donors that may fall within an organisation's area of activity. For example, NGOs such as Oxfam are banking on institutional donors, including governments and multilateral institutions. The rationale is that this type of donors are more resourceful in times of financial crisis and steadier in the long term (IRIN 2008) given the fact that it is government funds that are rescuing everyone else, including corporations, from financial troubles. Save the Children-UK is committed to cultivating more funding commitments from wealthy individuals.

Lastly, Kracher (2008) says that NGOs are seeking emergency or sustainability funds for rainy days. This strategy is not being proposed because of funding or resource uncertainty alone, but also in view of the fact that, even if an organisation has a contract with a donor, in financially sensitive times, donors tend to take longer to make decisions especially for large donations and they tend to stick with those non-profits they have funded in the past, and cut off those new on their list. Frank (2008) recommends that NGOs should find creative ways of making their funds especially large funds productive, and of generating extra funds. For example, they could open strategic accounts with their banks, they could provide consultancy services to other organisations utilising skills of their own staff, and an organisation's staff could contribute a percentage of their salary to the organisation (Frank 2008).

In conclusion, the current global economic crisis requires NGOs to find creative and innovative ways of not only surviving the times but also even potentially seizing them as an opportunity to stand up and make a significant difference. Such achievement is conditional on clearly ascertaining their funding situation that is, recognising the types of donors they rely on and the potential prospects or fall-outs that it may entail and drafting a way forward along the lines of cost-effectiveness, funding security and sustainability.

From the conceptualized framework herein, it was hoped that three main variables namely economic crises, management strategies and service delivery in the NGOs sub-sector were the focus of this study. The variables studied included level of funding, restructuring, policy change in reporting lines and service delivery in health, education, employment and skills, household incomes, savings and investments among others. The study examined how level of funding directly affects service delivery among NGOs and what management strategies have been put in place to intervene this occurrences. In this study, the independent variable was level of funding while the dependent variables are service delivery including health, education, employment and skills, household incomes, savings and investments. Therefore, the researcher intended to come up with strategies that would help any NGO to cope with future crises that may have an impact on service delivery.

\section{The Research Design and Methodology}

In order to address the gaps in the field of GEC the study adopted a descriptive survey design based on availability of data. The population included 30 NGOs, which is $4 \%$ of total number of NGOs that have their headquarters domicile in Nairobi City, Kenya. A total of 31 managers of NGOs formed the sample for this study and were picked through stratified sampling procedure (i.e. 20 lower-level and 11 middle-level managers). The managers oversee different programmes in their respective organizations. This sample size allowed for diversity of views and statistical analysis.

The data collection instrument was a semi-structured questionnaire which was self-administered to the project managers to collect primary data. The pre-testing was done in one of the NGOs that was not included in the sample. Data was analysed using the descriptive statistics and presented in form of tables. Statistical Package for Social Sciences (SPSS) was used to analyse the data.

\section{The Research Findings}

\subsection{Effect of Global Economic Crises on Management Strategies Observed in NGOs in Kenya}

Information on the effect of global economic crises on management strategies was sought in order to understand application of management strategies in diverse NGOs. Figure 2 shows these strategies and summarises these findings in form of percentages. The figure shows that most project managers (45.2\%) felt that restructuring was the major strategy employed. In this study restructuring meant reorganization of departments and work processes. This was 
followed closely by reduction in operations $38.7 \%$, while freeze on hiring scored $19.4 \%$. Worth noting were other methods that were employed which formed a sizeable percentage of $25.8 \%$. These included methods such as a freeze on staff benefits such as salaries and pay rise, leveraging other funding sources, change of priorities and diversification of funding sources as some of the methods NGOs used to cushion themselves from the effects of the global economic crises.

\subsubsection{Effect of GEC on Service Delivery}

The study was also interested in knowing whether the organizations had a change in their programme priorities as a result of GEC. Results from Table 2 indicate percentage scores of the responses. It can be noted that the majority of project managers (64.5\%) said their organizations were not affected by the global economic crises. This is an indicator that, although the crises had adverse effects in other countries it may not have affected organizations in East Africa that much. However, the $35.5 \%$ of those who indicated that they were affected by the crises is a sizeable percentage that cannot be ignored.

\subsubsection{Challenges that were Faced by the Organizations}

Due to the global economic crises, the project managers also indicated that they faced various challenges in their organizations as Table 3 shows. From the table reduction in project implementation or operation scale down, budget reduction or shrink, reduction in funding, freezing employment and staff turnover were the main challenges faced with a total of $87.1 \%$. Increased competition for consortium implementation and a closure of projects followed with $9.7 \%$ each while reduction in staff numbers at $6.5 \%$. Following these responses, the study concluded that despite majority of NGOs indicating that they were not directly affected by the GEC, still these challenges noted spoke volumes of the GEC effects on the organizations. This information on challenges that affected NGOs during the GEC is a pointer to the managers and administrators of NGOs on problems that need to be addressed in most urgent ways possible in order to avert future events such as the one observed.

On a similar note, the researcher was interested in finding out whether the challenges faced by the organizations affected service delivery. It can be noted from Table 4 that despite a majority of the project managers, 58.1\% responding that service delivery was not affected in any way, on the other hand $41.9 \%$ felt otherwise. This disparity though however, had some significance hence the researchers took this to mean service delivery was affected in one way or another among NGOs.

It was interesting to note that, for those who felt that due to the challenges they observed, in reality they faced setbacks in service delivery. Concerning how programme activities were affected, major responses included: reduced staff which in turn scaled down on operations, delays in supplier payments, non-achievement of organizational objectives, loss of quality programming, reduced number of projects, fraud and pilferage caused by staff uncertainty and anxiety, strain on staff as they use limited resources, decrease in community outreach worsening lives of communities, premature closure of projects and loss of confidence by communities. For example, one project manager was quoted saying:

There have been increased incidences of fraud and pilferage over time by staff; this has hampered operations due to numerous investigations that need to be undertaken thus, putting more efforts on trying to prevent fraud than delivery of service to beneficiaries.

Similarly, another said:

Less funding leads to reduced activities which has adverse effects such as high illiteracy.” ...reduced project implementation and therefore, reduced impact to communities we serve.

To add on, service delivery seems to have been affected in various ways. This was thought so after one World Vision East Africa project manager commented:

Premature closure of programme activities affects organization's strategies; going back will require more trust than before where the communities may fail to take WVK serious as before.

One project manager from Pact Kenya noted the following:

Staff have been looking out for other job opportunities outside the organization. This has resulted in high staff turnover which has impacted on service delivery. A lot of time has been spent on staff recruitment, selection, induction and training; hence, more resources have been spent, disruptions in operations and loss of morale on the part of staff who feel they are not making enough progress/impact as intended.

\subsubsection{Measures Used to Overcome the Challenges Faced by NGOs in Kenya}


The study was interested in finding out what measures were used to overcome the challenges hence enhance service delivery activities. Figure 3 shows that job realignments, $16.1 \%$, freeze on hiring $12.9 \%$, restricting and writing more proposals $9.7 \%$ respectively and reduction on implementation of programmes were the major ways that were used to mitigate the challenges NGOs faced during the GEC. Other methods used as indicated by respondents were using limited resources for capacity building and training of staff, sharing of assets across different projects, use of key staff available as some of the measure employed.

\subsection{Effect of the Level of Funding on Service Delivery}

\subsubsection{Changes in Programming Priority Adopted by NGOs in Delivery of Development Programs}

The study further sought for information on changes in priority adopted by the organizations in delivery of development programmes. Results concerning crisis prevention, emergency aid, crisis recovery, peace building, indicated a majority $71 \%$ of the respondents agreed that these programmes were given a between moderate and high priority while a minority of $12.9 \%$ of the project managers responded that they were given a low priority. In summary, the study concluded that most project managers agreed that indeed there was a change in priorities given to different projects and programmes in which they participate in. However, the opinions of those who tended to disagree with whether there was a change in priorities given in development programmes, small in percentages as they were couldn't be ignored. It is an indicator that some organizations were not keen to make a change in programming which may be due to the fact that they were not heavily affected by the GEC as earlier indicated.

\subsubsection{Changes in Resource Availability}

In order to have an overview of how organizations' resource availability changed respondents were required to indicate the changes they witnessed in their budgets in years 2008 and 2009 respectively. Table 5 clearly shows that a majority (35.5\%) and (32.3\%) surprisingly noted an increase in their budgets in both years 2008 and 2009 respectively with a few (16.1\%) indicating a budget decrease. However, it can be noted that in 2009 there was a slight decrease in budget compared to 2008. This was interpreted to mean that it might be due to intensified efforts in fundraising and the programmes that favour an increase in funding that the NGOs engage in such as HIV/AIDs and poverty reduction.

\subsection{Strategic Policy Implications}

In order to overcome the challenges of GEC, different NGOs applied different methods. However, these did not vary from the organizations and that most strategies applied could not be singled out and used independently. Table 6 indicates that a majority $32.3 \%$ felt that their organizations adapted to higher resource constraints, followed closely by starting additional fundraising campaign 29\%, narrowing scope of its work 19.4\%. Cutting on the number of its staff scored $16.1 \%$ while $9.7 \%$ of the respondents indicated that there was a reduction of resources, which lead to better efficiency of work. Other approaches used included networking with local NGOs and use of technology such as the internet tools to do their work. In conclusion, the study found that according to project managers, higher resource constraints, fundraising campaigns, narrowing the scope of work and reducing the number of staff were some of the major strategies adopted by the NGOs to cushion themselves from the effects of the global economic crises that was being experienced in years 2008 and 2009. Other ways suggested in which the organizations need to focus on as a wakeup call in the event of an economic crisis were the need to diversify their donors, through submitting more proposals, getting resources locally and managing staff expectations and concerns.

\section{Conclusion}

From the above analysis, it is clear that NGOs in Kenya were affected in their provision of services during the 2008 and 2009 when the effects of the GEC were felt. Several strategies were identified to have been employed during the global crises. These included; restructuring reduction in operations, freeze on hiring, freeze on staff benefits such as salaries and pay rise, leveraging other funding sources, change of priorities and diversification of funding sources. Several mitigating ways were utilized to cushion the organisations from GEC effects such as job realignments, freeze on hiring, restricting and writing more proposals and reduction on implementation of programmes. Other methods were utilization of limited resources for capacity building and training of staff, sharing of assets across different projects and use of key staff available. These had implications on strategy in that, organisations adapted to higher resource constraints, started additional fundraising campaigns, narrowed scope of their work and reduced resources, this lead to better efficiency of work.

\subsection{Policy Recommendations}

From the findings of the study, the following recommendations were made so that NGOs can benefit in terms of cushioning themselves in the event of such a crisis occurring in the future. Organizations need to focus on diversifying 
their sources of funding by finding creative ways of making their funds productive, and of generating extra funds. For example, they could provide consultancy services to other organizations utilizing skills of their own staff or open strategic accounts with banks. This would act as a booster to the organizations operations during crisis times. Similarly, NGOs need to find creative and innovative ways of not only surviving the times but also even potentially seizing them as an opportunity to stand up and make a significant difference. Such achievement is conditional on clearly ascertaining their funding situation recognizing the types of donors they rely on and the potential prospects or fall-outs that it may entail and outline a way forward along the lines of cost-effectiveness, funding security and sustainability. As a joint action by NGOs through advocacy to discourage cuts in development assistance, such advocacy effort will need leadership in mobilization, sharing knowledge, developing coherent messages and coordination among actors. Agreements can be developed among management and staff on clear criteria and measures to manage reserves, unrestricted funds, and investment decisions can be utilized. Lastly, NGOs can form cross-functional situational management team where members of this team could familiarize themselves with the effects of the crisis, monitor the unfolding issues at all levels and recommend to senior management of their institutions specific measures to prevent or address negative effects on all aspects of organizational capacity like programming, human resources, and resource stewardship.

\section{References}

Adamu, A. (2009). The effects of global financial crisis on Nigerian economy. [Online] Available: http://www.rrojasdatabank.info/crisisdb/onnigeria09.pdf.

Africa Progress Panel, (2008). Africa's Development: Promises and Prospects. Geneva. [Online] Available: www.africaprogresspanel.org.

African Development Bank, (2009). Impact of the global financial and economic crisis on Africa. [Online] Available: www.un.rg/ga/econcrisissummit/docs/full_contributions.pdf

Bowman, V. (2007). The UN and NGOs in Nairobi. [Online] Available: http://www.studio-base.com/project/Nairobi/student-work/UN/NGOsin Nairobi.

Chossudovsky, M. (2008). If Foreign Aid Contracts, Aids Treatment Jobs are a Safe Bet: Development Impact of Financial Crisis. Global Financial Crisis. Ottawa: University of Ottawa.

Cipriani, M., and Guarino, A. (2008). Herd behaviour and contagion in financial markets. The B.E. Journal of Theoretical Economics 8(1), Article 24, pp. 1-54

Cooper, D. R., and Schindler, P. S. (2003). Business research methods. 8th ed. Tata McGraw-Hill Publishing Company Limited. New Delhi.

Danylyshyn, B. (2008). Global Financial Crisis: A Test for Ukraine. Speech by Minister of Economy of Ukraine, Ukraine: Ministry of Economy.

FAO (2009). More People Than Ever Are Victims of Hunger. Global Information and Early Warning System on Food and Agriculture (GIEWS). [Online] Available: http://www.fao.org/giews/english/alert/index.htm.

Frank, J. (2008). Attention: South African NGOs and CBOs: 18 Ideas for Avoiding a Funding Crisis, Consultancy report, South Africa: Ford Foundation.

Frenkel, R. \& Rapetti, M. (2009). Some Reflections on the Current Global Crisis from a Developing Countries Perspective. Friedrich-Ebert-Stiftung (FES) Briefing Paper 6. [Online] Available: from www.fes-organization .org.

Ghanim, I. (2009). The Global Financial Crisis and International NGOs. [Online] Available: www.africanchild.info/index.php?file=Financial_Crisis_INGO.pdf

Gross, D. (2008). The Coming Charity Crisis: How the struggling economy is hurting donations. [Online] Available: www.newsweek.com

Hanfstaengl, E. M. (2009). The Global economic crisis and its impact on Civil Society Organizations. Friedrich Ebert Stiftung: New York. [Online] Available: http://ngosocdev.files.wordpress.com/2010/01/study-on-impact-of-global-crises-on-csos.pdf

Hilsenrath, J. et al, (2008). Worst Crisis Since '30s' With No End Yet in Sight. The Wall Street Journal, Washington: Dow Jones \& Company.

Ho, A. (2008). Philanthropy and economic crisis. Asian-American Philanthropy Journal (AAPJ), Washington: The Council on Foundations. 
IMF Multimedia Services Division, (2009). Impact of the Global Financial Crisis on Sub Saharan Africa.

Integrated Regional Information Networks, IRIN, (2008). NGOs Pare Down in Face of Financial Crisis. [Online] Available: www.irinnews.org.

International Labour Organization, ILO, (2009). World of Work Report: Global Jobs Crisis and Beyond. [Online] Available: www.ilo.org.

International Monetary Fund, IMF, (2009). World Economic Outlook.

Kindleberger. C. P., and Aliber, R. (2005). Manias, Panics, and Crashes: A History of Review of Sociology. 21 p. 387-417.

Kracher, J., (2008). Donors Forum: Strengthening Illinois Philanthropy and the non-profit community coping with Economic Uncertainty, Forum notes, Illinois: Illinois Nonprofit Principles and Best Practices

Krugman, P. (2008). The widening gyre, New York Times. [Online] Available: http://www.nytimes.com/2008/10/27/opinion/27krugman.html

Laeven, L., and Valencia, F. (2008). Systemic banking crises: a new database InternationalMonetary Fund Working Paper 08/224.

Mwega, M., F. (2009). Global Financial Crisis Discussion Series Paper 7: Kenya. School of Economics, University of Nairobi.

Naomi Hossain (2009). Crime and Social Cohesion in the Time of Crisis: Early Evidence of Wider Impacts of Food, Fuel and Financial Shocks, IDS Bulletin. 40, Issue 5.

Ngumuta, S. (2008). World Vision in Kenya. [Online] Available: http://www.worldvision.org.

Njoroge, J. (2009). Effects of the global financial crisis on corporate social responsibility in multinational companies in Kenya. Paper presented at Ethical Information Analyst Intern, Covalence SA, Geneva.

Onyando M., R. (1999). Are NGOs essential for Kenya's development? [Online] Available: http://www.netnomad.com/NGOSDN.html

Sender J. \& Uexkull E. V. (2009). A rapid impact Assessment of the Global economic Crisis on Uganda. International Labour Office. Geneva: ILO. [Online] Available: www.ilo.org

Teka, Z. and Magezi, V. (2008). Global financial crisis and donor funding implications: should NGO beneficiaries be concerned? Aids Foundation of South Africa. [Online] Available: www.aids.org.za/downloads/financial_crisis.pdf

UN, (2009). Statistics Department calculations based on World Bank estimates in Global Economic Prospects. [Online] Available: www.UN.org.

United Nations, (2010). World Economic Situation and Prospects. [Online] Available: www.UN.org.

World Bank, (2008). 'Global Food and Fuel Crisis Will Increase Malnourished by 44 Million', Press release (No. 2008/107/EXC). [Online] Available: www.worldbank.org.

World Bank, (2009). The Impact of the Financial Crisis on Progress towards the Millennium Development Goals in Human Development', Internal Policy Note. [Online] Available: www.worldbank.org.

World Bank, (2009). World development indicators. [Online] Available: http://data.un.org.

\section{Notes}

Note1. Local Development Organisation in this study is a term that is used to mean non-governmental organisation.

Note 2. Restructuring meant reorganization of departments and work processes. 
Table 1. Non-Governmental Organizations that participated in the study

\begin{tabular}{|l|l|c|}
\hline & Name & Frequency \\
\hline 1. & Adra Somalia & 1 \\
\hline 2. & African Education Trust & 2 \\
\hline 3. & Care Somalia & 1 \\
\hline 4. & Christian Aid & 3 \\
\hline 5. & CIMMYT - International Maize and Wheat Improvement Centre & 2 \\
\hline 6. & Engender Health & 1 \\
\hline 7. & FAO & 2 \\
\hline 8. & Food for the Hungry & 1 \\
\hline 9. & ICIPE & 1 \\
\hline 10. & ILRI & 1 \\
\hline 11. & Management Systems International & 1 \\
\hline 12. & Pact Kenya & 1 \\
\hline 13. & Pathfinder International & 1 \\
\hline 14. & Plan International & 1 \\
\hline 15. & Save the Children UK & 3 \\
\hline 16. & Save the Children USA & 1 \\
\hline 17. & VSF Germany & 1 \\
\hline 18. & VSF Suisse & 1 \\
\hline 19. & World Food Programme & 1 \\
\hline 20. & World Vision East Africa & 1 \\
\hline 21. & World Vision Kenya & 1 \\
\hline & Total & 1 \\
\hline
\end{tabular}

Table 2. Whether NGOs had a change in program priority

\begin{tabular}{|l|c|c|}
\hline & Frequency & Percent \\
\hline Yes & 11 & 35.5 \\
\hline No & 20 & 64.5 \\
\hline Total & 31 & 100.0 \\
\hline
\end{tabular}


Table 3. Challenges Faced by NGOs during the GEC ( $\mathrm{N}=31)$

\begin{tabular}{|l|c|c|}
\hline Challenge & F & $\%$ \\
\hline Reduction in project implementation/operation scale down & 7 & 22.6 \\
\hline Budget reduction/shrink & 6 & 19.4 \\
\hline Reduction in funding & 5 & 16.1 \\
\hline Freezing employment & 5 & 16.1 \\
\hline Uncertainty among staff leading to staff turnover & 4 & 12.9 \\
\hline Increased competition for consortium implementation & 3 & 9.7 \\
\hline Close of projects & 3 & 9.7 \\
\hline Reduced staffing/retrenchment & 2 & 6.5 \\
\hline Reduction in private contributions & 1 & 3.2 \\
\hline Reduction in capital purchases & 1 & 3.2 \\
\hline Increased cost of imported products & 1 & 3.2 \\
\hline
\end{tabular}

Table 4. Whether Challenges Faced by NGOs Affected Service Delivery

\begin{tabular}{|l|c|c|}
\hline & Frequency & Percent \\
\hline Yes & 13 & 41.9 \\
\hline No & 18 & 58.1 \\
\hline Total & 31 & 100.0 \\
\hline
\end{tabular}

Table 5. Cross Tabulations of Changes in Budgets in Years 2008 and 2009

\begin{tabular}{|c|c|c|c|c|c|c|}
\hline & & \multicolumn{4}{|c|}{ Year 2009} & \multirow[b]{2}{*}{ Total } \\
\hline & & Not stated & Budget increase & No Change & Budget Decrease & \\
\hline \multirow{4}{*}{$\begin{array}{l}\text { Year } \\
2008\end{array}$} & Not stated & $8(25.8)$ & 1(3.2\%) & 0 & 0 & $9(29 \%)$ \\
\hline & Budget increase & 0 & $8(25.8)$ & $2(6.5 \%)$ & $1(3.2 \%)$ & $11(35.5 \%)$ \\
\hline & No Change & 0 & $1(3.2 \%)$ & $5(16.1 \%)$ & 0 & $6(19.4 \%)$ \\
\hline & Budget Decrease & $1(3.2 \%)$ & 0 & 0 & $4(12.9 \%)$ & $5(16.1 \%)$ \\
\hline & Total & $9(29 \%)$ & $10(32.3 \%)$ & $7(22.6 \%)$ & $5(16.1 \%)$ & $31(10 \%)$ \\
\hline
\end{tabular}


Table 6. Strategies Adopted by Organizations

\begin{tabular}{|ll|c|c|c|}
\hline Strategy & F & $\%$ & Rating \\
\hline a. $\quad$ Organizations adapted to higher resource constraints & 10 & 32.3 & 1 \\
\hline b. $\quad$ Organization started an additional fundraising campaign & 9 & 29.0 & 2 \\
\hline c. $\quad$ Organization narrowed the scope of its work & 6 & 19.4 & 3 \\
\hline d. $\quad$ Organization substantially reduced the number of its staff & 5 & 16.1 & 4 \\
\hline e. $\quad$ Reduced resources which lead to better efficiency of work & 3 & 9.7 & 5 \\
\hline f. $\quad$ Sought networking with local NGOs & 2 & 6.5 & 6 \\
\hline g. & Additional skills were developed using internet tools & 2 & 6.5 & 7 \\
\hline
\end{tabular}

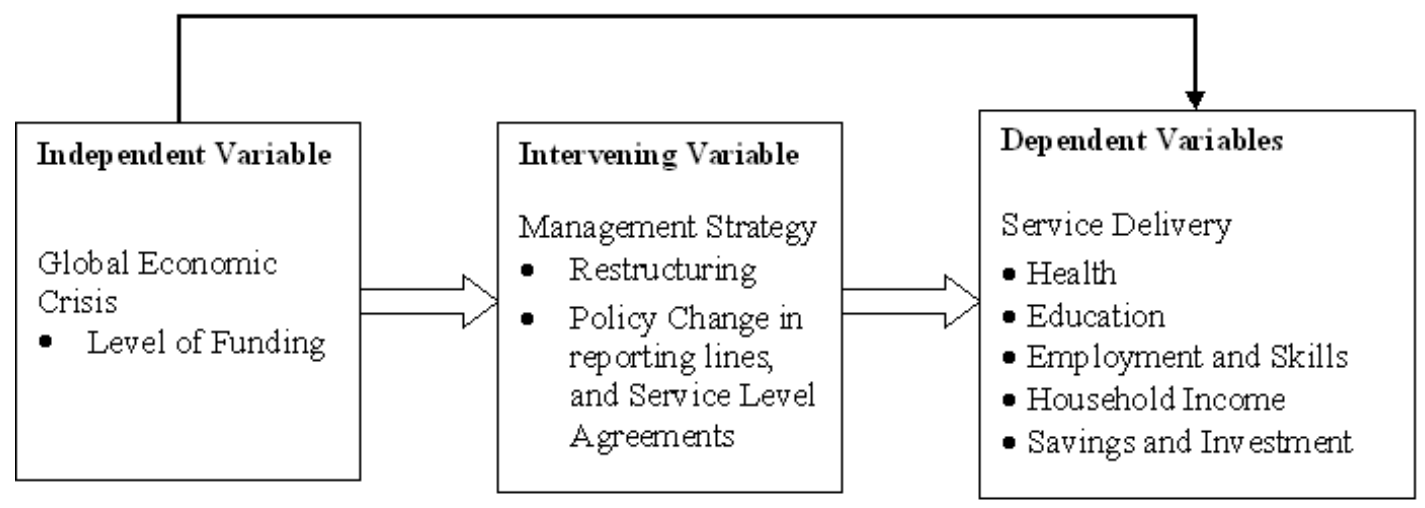

Figure 1. The Conceptual Framework on the Effects of the Global Economic Crisis on Service Delivery in the NGOs sector

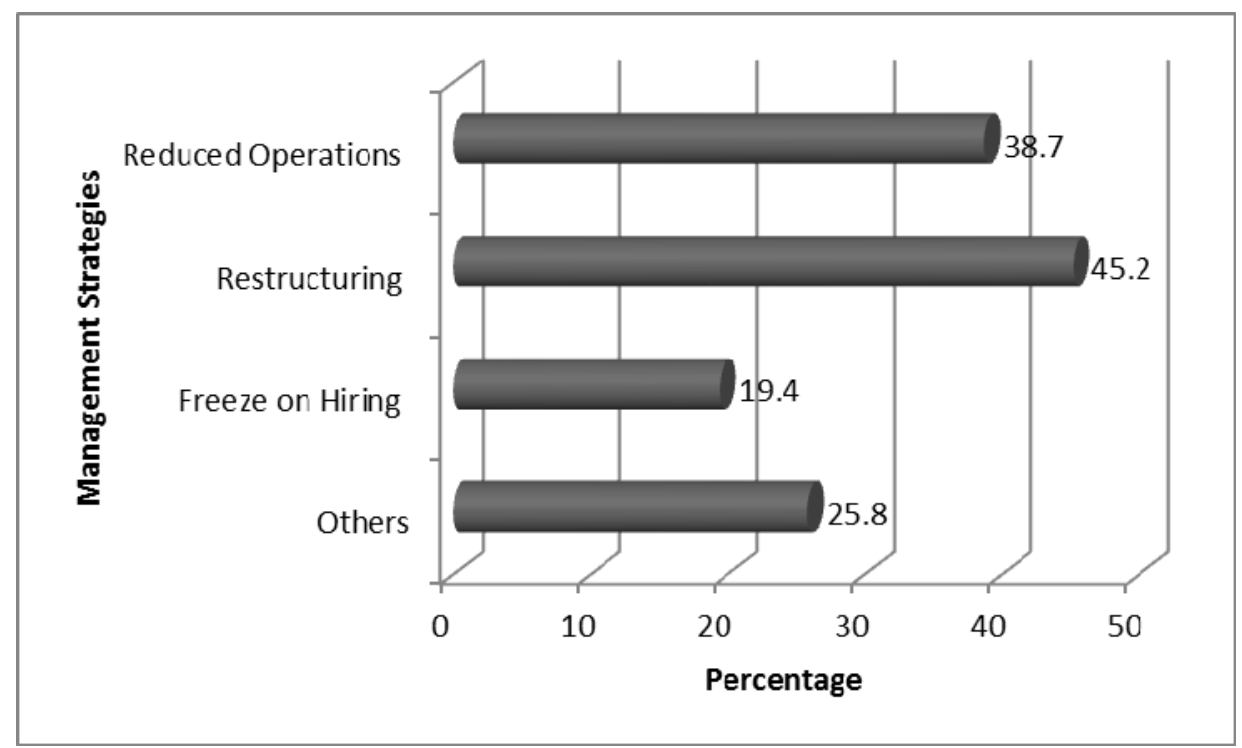

Figure 2. Management strategies observed in NGOs as a result of Global Economic Crises (N=31) 


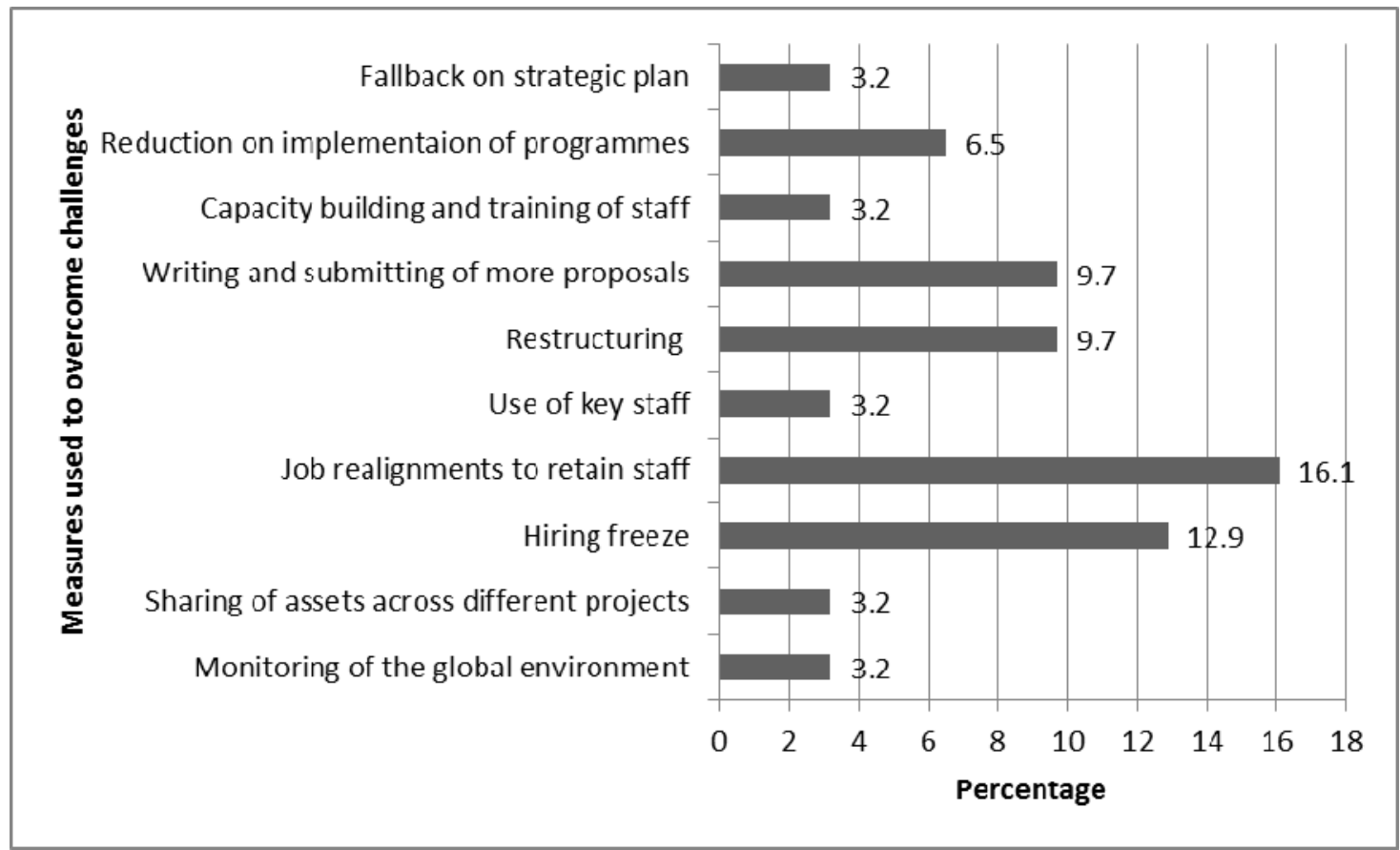

Figure 3. Measures Employed 